beneficial as measured by a priori outcomes. Combined VR and conventional training appears to be beneficial compared to VR training alone. VR curricula grounded in educational theory, such as a progressive learning-based curriculum, provided benefit regarding composite score of competency. Definitive evidence for or against VR training in place of conventional training or another form of simulation is lacking.

\begin{tabular}{|c|c|c|c|}
\hline Outcome & Studies (n) & Procedures (n) & Effect Size \\
\hline \multicolumn{4}{|c|}{ Simulation training versus no training } \\
\hline Composite Score of Competency & 1 & 24 & $0.73[-0.10,1.57]^{*}$ \\
\hline Procedure Completion & 6 & 815 & $1.62[1.15,2.26]{ }^{\dagger}$ \\
\hline Time & 2 & 29 & $-0.39[-1.13,0.35]^{*}$ \\
\hline Discomfort & 2 & 200 & $-0.30[-0.89,0.29]^{*}$ \\
\hline Global Rating Competency & 1 & 36 & $1.43[0.67,2.19]^{*}$ \\
\hline Mucosal Visualisation & 1 & 55 & $0.79[0.24,1.34]^{*}$ \\
\hline \multicolumn{4}{|c|}{ VR simulation training versus conventional training } \\
\hline Procedure Completion & 2 & 174 & $0.45[0.27,0.74]^{\dagger}$ \\
\hline Time & 2 & 34 & $0.12[-0.55,0.80]^{*}$ \\
\hline Global Rating of Competency & 1 & 16 & $-0.23[-1.22,0.76]^{*}$ \\
\hline Mucosal Visualisation & 1 & 18 & $0.00[-0.92,0.92]^{*}$ \\
\hline
\end{tabular}

Conclusion VR training can effectively supplement early conventional endoscopy training. Comparative effectiveness studies of different simulation modalities are limited. Newer trials provide insight into simulation training approaches grounded in educational theory that improve subsequent clinical performance.

\section{PTH-141 THE LEARNING CURVE FOR POLYPECTOMY AND ENDOSCOPIC MUCOSAL RESECTION (EMR): A SYSTEMATIC REVIEW}

${ }^{1}$ Arun Rajendran*, ${ }^{2}$ Samuel Pannick, ${ }^{3}$ Siwan Thomas-Gibson, ${ }^{3}$ Chukwemeka Anele, ${ }^{3}$ Siddartha Oke, ${ }^{1}$ Nick Sevdalis, ${ }^{3}$ Adam Haycock. ${ }^{1}$ King's College London UK ${ }^{2}$ Charing Cross Hospital, UK ${ }^{3}$ St Mark's Hospital, UK

\subsection{6/gutjnl-2018-BSGAbstracts.540}

Introduction Lower gastrointestinal (LGI) endoscopy has evolved from being a diagnostic procedure to include therapeutic procedures such as polypectomy and EMR. For training purposes, there is a need to define the learning curve (LC) and competency markers for these procedures.

Methods A systematic review of the literature from 1946 to August 2016 was conducted by searching Pubmed, Embase and Web of Science. The search strategy used key $\mathrm{MeSH}$ terms and text words related to LC in LGI polypectomy and EMR. Full-text review of eligible studies and a quality appraisal (modified Down's and Black scale ${ }^{2}$ ) was performed for each identified study. Outcome measures were analysed to try to identify LC and competency markers.

Results Initial database search identified 754 articles and after applying exclusion criteria, 3 articles for polypectomy and 3 articles for EMR were identified for review. A variable range of predefined outcome measures were used to calculate LC and technical competence in the included studies.

Table 1 summarises the LC studies on polypectomy. Choung et al. ${ }^{3}$ noted a $<1.2 \% \mathrm{DPPB}^{*}$ rate for endoscopists who had performed $>400$ polypectomies, which was below the $2 \%$ predefined cut-off. In Boo et al. ${ }^{4}$, the enbloc resection rate for trainees increased steadily $\&$ average CP time decreased significantly with experience $(\mathrm{p}<0.001)$. The success rate of $>80 \%$ was achieved by trainees after 250 snare polypectomies. Patwardhan

\begin{tabular}{|c|c|c|c|c|c|c|c|c|}
\hline \multirow[t]{2}{*}{ Study } & \multirow{2}{*}{$\begin{array}{c}\text { No: } \\
\text { of } \\
\text { trainees } \\
\text { (n) }\end{array}$} & \multicolumn{2}{|c|}{$\begin{array}{c}\text { Previous } \\
\text { experience of } \\
\text { trainees }\end{array}$} & \multirow[t]{2}{*}{$\begin{array}{c}\text { Size of polyps } \\
\text { included in the } \\
\text { study }\end{array}$} & \multirow[t]{2}{*}{$\begin{array}{c}\text { Type } \\
\text { of polypectomy }\end{array}$} & \multirow{2}{*}{$\begin{array}{c}\text { No: of snare } \\
\text { polypectomies } \\
\text { performed by } \\
\text { trainees }\end{array}$} & \multirow[t]{2}{*}{$\begin{array}{l}\text { Outcome } \\
\text { measure }\end{array}$} & \multirow{2}{*}{$\begin{array}{l}\text { Learning curve } \\
\text { no. of cases: } \\
\text { outcome measure } \\
\text { achieved } \\
\text { (n) }\end{array}$} \\
\hline & & $\begin{array}{l}\text { Colons } \\
\text { (n) }\end{array}$ & $\begin{array}{l}\text { CP } \\
\text { (n) }\end{array}$ & & & & & \\
\hline Choung 2014 & 15 & $>300$ & - & $>5 \mathrm{~mm}$ & $\begin{array}{c}\text { Snare } \\
4310(72.0 \%) \\
\text { Biopsy } \\
1528(25.5 \%) \\
\text { EMR } \\
143(2.5 \%)\end{array}$ & 5981 & $\begin{array}{l}\text { Delayed Post } \\
\text { Polypectomy } \\
\text { Bleeding } \\
\text { (DPPB) }\end{array}$ & $>400$ polypectomies \\
\hline Boo 2015 & 3 & $>150$ & 30 & $\begin{array}{c}>5 \mathrm{~mm}, \\
<15 \mathrm{~mm} \text { (sessile) } \\
<20 \mathrm{~mm}^{*} \\
\text { (pedunculated) }\end{array}$ & $\begin{array}{c}\text { Snare } \\
750(100 \%)\end{array}$ & 750 & $\begin{array}{c}\text { Enbloc } \\
\text { resection } \\
\text { Colonoscopic } \\
\text { Polypectomy } \\
\text { (CP) time }\end{array}$ & 250 polypectomies \\
\hline $\begin{array}{l}\text { Patwardhan } \\
2016\end{array}$ & 10 & - & - & - & $\begin{array}{l}\text { Cold snare } 924 \\
(91.6 \%) \\
\\
\text { Hot snare } 85 \\
(8.4 \%)\end{array}$ & 1009 & $\begin{array}{c}\text { Independent } \\
\text { unassisted } \\
\text { polypectomy } \\
\text { completion } \\
\text { rate }\end{array}$ & $\begin{array}{c}>90 \% \text { after } 300 \\
\text { (colons) } \\
>95 \% \text { after } 700 \\
\text { (colons) }\end{array}$ \\
\hline
\end{tabular}


Abstract PTH-141 Table 2 Summary of EMR learning curve studies

\begin{tabular}{|c|c|c|c|c|c|c|c|}
\hline Study & $\begin{array}{l}\text { No: of } \\
\text { trainees }\end{array}$ & $\begin{array}{l}\text { Previous } \\
\text { experience }\end{array}$ & Mentorship & $\begin{array}{l}\text { Size of polyps } \\
\text { included in } \\
\text { study }\end{array}$ & $\begin{array}{l}\text { No: of } \\
\text { EMRs' } \\
\text { performed } \\
\text { by trainees } \\
\text { (n) }\end{array}$ & $\begin{array}{l}\text { Outcome } \\
\text { measure }\end{array}$ & $\begin{array}{l}\text { Learning } \\
\text { curve no. of } \\
\text { EMR cases: } \\
\text { outcome } \\
\text { measure } \\
\text { achloved } \\
\text { (n) }\end{array}$ \\
\hline $\begin{array}{c}\text { Bhurwal } \\
2016\end{array}$ & 3 & $\begin{array}{c}\geq 5 \text { years' } \\
\text { gastroenterology } \\
\text { experience }\end{array}$ & Not defined & $\begin{array}{c}>20 \mathrm{~mm} \\
(\text { median }=30)\end{array}$ & 578 & $\begin{array}{c}\text { Residual } \\
\text { neoplasia at } \\
<24 \text { months follow- } \\
\text { up } \\
\text { Endoscopist } \\
\text { assessment of } \\
\text { incomplete EMR }\end{array}$ & 100 \\
\hline $\begin{array}{l}\text { Lamb } \\
2012\end{array}$ & 1 & $\begin{array}{l}\text { Competent in } \\
\text { colonoscopy** }\end{array}$ & $\begin{array}{l}\text { BCSP* colonoscopist, with } \\
\text { level } 4 \text { polypectomy } \\
\text { competency as mentor } \\
\text { throughout the early } \\
\text { period of training }\end{array}$ & $>20 \mathrm{~mm}$ & 129 & $\begin{array}{c}\text { Recurrence at } 3 \mathrm{~m} \\
\text { Bleeding }\end{array}$ & 50 \\
\hline $\begin{array}{l}\text { Choi } \\
2015\end{array}$ & 7 & $\begin{array}{c}>2 \mathrm{yrs} \text { of } \\
\text { experience } \\
>500 \text { OGD's \& } \\
>50 \\
\text { sigmoidoscopies } \\
\text { /yr }\end{array}$ & $\begin{array}{l}\text { Performed CP under } \\
\text { supervision of expert } \\
\text { endoscopists for } 1 \text { month }\end{array}$ & $\begin{array}{c}5-9 \mathrm{~mm} \\
(75.6 \%) \\
\\
10-19 \mathrm{~mm} \\
(20.6 \%) \\
>20 \mathrm{~mm} \\
(3.8 \%) \\
\end{array}$ & 2080 & $\begin{array}{l}\text { Complete } \\
\text { resection }\end{array}$ & 300 \\
\hline
\end{tabular}

"An accredited Bowel Cancer Screening Programme colonoscopist, " Competent in colonoscopy as defined by JAG, UK'

et al. ${ }^{5}$ noted that rates of independent snare polypectomy were consistently $>90 \%$ after 300 colonoscopies $\&>95 \%$ after 700 colonoscopies.

Table 2 summarises the LC studies in EMR. Bhurwal et $\mathrm{al}^{6}$ observed that after 100 EMR procedures, the proportion of residual neoplasia (recurrence) at $<2$ years follow up was $<20 \%$ $\&$ the frequency of incomplete EMR was between $20 \%-25 \%$. Lamb et $\mathrm{al}^{7}$ showed that the recurrence rates at 3 months \& adverse events (bleeding \& perforation) were comparable after 50 EMR procedures. Choi et $\mathrm{al}^{8}$ demonstrated that complete resection rates increased significantly from $37.4 \%$ within the first 100 EMRs to $57.6 \%$ after 300 EMRs (on par with the expert group).

Conclusions There are very few studies examining the LC of polypectomy and EMR with wide variation in LC. Several outcome measures were identified that could be used to assess competency in polypectomy (DPPB, recurrence, and polypectomy completion rate) and EMR (recurrence and bleeding). There is a need for more robust studies to further understand the LC of polypectomy and EMR. Current training guidelines for polypectomy and EMR require further evaluation.

\section{REFERENCES}

1. JAG (UK) 2011

2. Downs, et al. 1998

3. Choung, et al. 2014

4. Boo, et al. 2015

5. Patwardhan, et al. 2016

6. Bhurwal, et al. 2016,

7. Lamb, et al. 2012

8. Choi, et al. 2011

\section{PTH-142 \\ SAFER STEPS: BARRIERS TO IMPLEMENTING SAFETY INTERVENTIONS IN A MULTI-SITE ENDOSCOPY SERVICE}

Margaret Scott*, Richard Thomson, Leigh Donnelly*, Tom Lee. Northumbria Healthcare Foundation Trust, Newcastle Upon Tyne, UK

\subsection{6/gutjnl-2018-BSGAbstracts.541}

Introduction World Health Organisation (WHO) checklisting is a recommended step prior to every endoscopic procedure with the potential to positively impact on patient morbidity and mortality if used effectively. Research in other settings demonstrates reduced error and improved safety where checklists are widely used, however there is evidence to suggest that significant investment is required in terms of multi-professional team-based training in order to improve safety behaviour. This study aimed to identify barriers to implementation of check listing as part of a Safer Steps programme in a large multi-site endoscopy suite.

Methods The study setting was a large endoscopy service based in the North of England. The service incorporates 32 endoscopists and 80 nurses working across 5 sites over a large geographical area. A round table exercise was conducted at a service away day. 70 nurses, administrative staff, endoscopists and managers contributed. Participants were asked to identify 'challengers' and 'enablers' to use of and pre-endoscopy checklist as part of safer steps programme including pre-list huddle, preprocedure time out, post-procedure sign-off and post-list debrief. Discussions were documented and subjected to thematic analysis.

Results Frequently encountered themes included: 


\begin{tabular}{ll} 
Abstract PTH-142 Table 1 & TEAM BRIEF - 'The Huddle' \\
\hline CHALLENGES & ENABLERS \\
\hline Complacency & Unit staff drivers for huddle \\
Distractions & Motivation of unit staff \\
Hierarchy & Equipment needed/problems identified \\
Lack of consistency & Introductions and roles identified \\
Non-compliance & Knowing what to expect from the list \\
Familiarity & \\
Lack of assertiveness & \\
\hline
\end{tabular}

\begin{tabular}{|c|c|}
\hline \multicolumn{2}{|c|}{ Abstract PTH-142 Table 2 TIME OUT - 'The Pause' } \\
\hline CHALLENGES & ENABLERS \\
\hline $\begin{array}{l}\text { Not everyone recognises the value of time } \\
\text { out }\end{array}$ & Brings the team together \\
\hline Becomes a 'tick box' exercise & Patients kept safe \\
\hline Poor time management & $\begin{array}{l}\text { Makes everyone aware of risks and to } \\
\text { remind each other }\end{array}$ \\
\hline $\begin{array}{l}\text { Getting everyone together at the same } \\
\text { time }\end{array}$ & $\begin{array}{l}\text { When everyone participates risks are } \\
\text { highlighted }\end{array}$ \\
\hline $\begin{array}{l}\text { Loss of focus during timeout, concentrating } \\
\text { on other tasks }\end{array}$ & $\begin{array}{l}\text { Identifies patient alerts, consent, medical } \\
\text { conditions, allergies }\end{array}$ \\
\hline \multicolumn{2}{|c|}{ Distractions } \\
\hline \multicolumn{2}{|l|}{ Starting time out before all staff are in the } \\
\hline Sign out not signed & \\
\hline
\end{tabular}

\begin{tabular}{|c|c|}
\hline CHALLENGES & ENABLERS \\
\hline Time constraints & Right patient, right report and right diagnosis \\
\hline $\begin{array}{l}\text { Entire team not always } \\
\text { present for sign out }\end{array}$ & $\begin{array}{l}\text { Two nurses checking reports and specimens before next } \\
\text { patient arrives in the room }\end{array}$ \\
\hline
\end{tabular}

\begin{tabular}{ll} 
Abstract PTH-142 Table 4 & DEBRIEF \\
\hline CHALLENGES & ENABLERS \\
\hline $\begin{array}{l}\text { Debrief does not happen } \\
\text { Endoscopists leaving department without checking patients }\end{array}$ & $\begin{array}{l}\text { Boosts morale } \\
\text { Identifies any issues }\end{array}$ \\
\hline
\end{tabular}

Conclusions Endoscopy staff report that human factors present barriers to the performance of checklisting.

There is a need to further explore the relationship between direct observation of practice and non-technical skills and whether training in human factors for endoscopy teams can reduce adverse events and improve safety behaviour.

\section{PTH-143 MEDICAL STUDENTS' PERCEPTION OF UNDERGRADUATE HEPATOLOGY TEACHING IN THE UK - A NATIONAL SURVEY}

'Lubiana Leara Shabeer*, '2Shahid A Khan. 'School of Medicine, University of Leeds, Leeds, UK ${ }^{2}$ Department of Hepatology. St Mary's Hospital. Imperial College London Healthcare NHS Trust, UK

\subsection{6/gutjnl-2018-BSGAbstracts.542}

Introduction Exposure to and teaching of clinical Hepatology during training at UK medical schools is anecdotally limited. Due to rising mortality rates, addressing liver disease has been identified as a national clinical priority and raises the question of whether Hepatology teaching on undergraduate curriculums is adequate for the increasing demand. To date, there has been no evaluation of the undergraduate Hepatology curriculum.

The aim of this study was to assess final year UK medical students' attitudes towards their current hepatology curriculum and their confidence of knowledge regarding hepatologyrelated clinical conditions.

Methods 31 UK medical schools were approached to partake in this study. 10 medical schools gave permission to distribute our 9-question online questionnaire to their students. Responses were collected over ten weeks following two rounds of local advertising. Ethical permission was obtained from the Medical Education Ethics Committee, Reference MEEC1617-45.

Results 123 responses were obtained from 10 UK based universities. The undergraduate medical education in Hepatology was rated as poor or unsatisfactory by $47.2 \%$ of respondents. $67.5 \%$ of participants strongly agreed or agreed that the inclusion of a Hepatology rotation would be useful to students and should be in the curriculum. Completing an additional component, such as student selected module, in hepatology was associated with higher confidence levels in key hepatology-related conditions.

Conclusions This is the first study to look at medical students' perception of clinical Hepatology teaching in the undergraduate curriculum. High levels of inadequacy associated with the current teaching suggest the need for a revised curriculum. There is potential to increase Hepatology exposure to students through optional modules and a mandatory Hepatology rotation, to improve confidence levels and equip students for the future challenges with liver disease.

\section{PTH-144 ALIGNING JETS SEDATION KEY PERFORMANCE INDICATOR MEASUREMENTS WITH CURRENT UK STANDARDS: IMPACT ON TRAINEE OUTCOME} ${ }^{1,2}$ Keith Siau*, ${ }^{2}$ Matthew D Rutter, ${ }^{2}$ Thomas JW Lee, ${ }^{1}$ Raphael Broughton, ${ }^{2}$ Geoff Smith,
${ }^{1,2}$ Paul Dunckley. ${ }^{1}$ Joint Advisory Group, London, UK ${ }^{2}$ National Endoscopy Database
Working Group, London, UK

\subsection{6/gutjnl-2018-BSGAbstracts.543}

Background The measurement of sedation KPIs in colonoscopy varies between JETS certification criteria and recent UK standards. To align standards in preparation for the National Endoscopy Database (NED), changes were recently made on JETS: 1) measuring average sedation doses, when used, with mean vs. median, and 2) reducing the maximum recommended midazolam dose in patients aged $70+$ from mean of $2.5 \mathrm{mg}$ to median of $2 \mathrm{mg}$. We aimed to explore the impact of these changes on trainee outcomes of exceeding recommended average doses.

Methods Sedation KPIs for midazolam [M], fentanyl [F] and pethidine $[\mathrm{P}]$ were extracted from the JETS e-Portfolios of trainees awarded provisional colonoscopy certification (PCC) between June 2011-2016, and stratified by drug and age $(<70$ vs. $70+)$. Calculations were applied at trainee level in the 50 procedures pre-PCC. Unsedated procedures were excluded. Normality testing was performed using the ShapiroWilk method, with skewed data expressed in medians and 

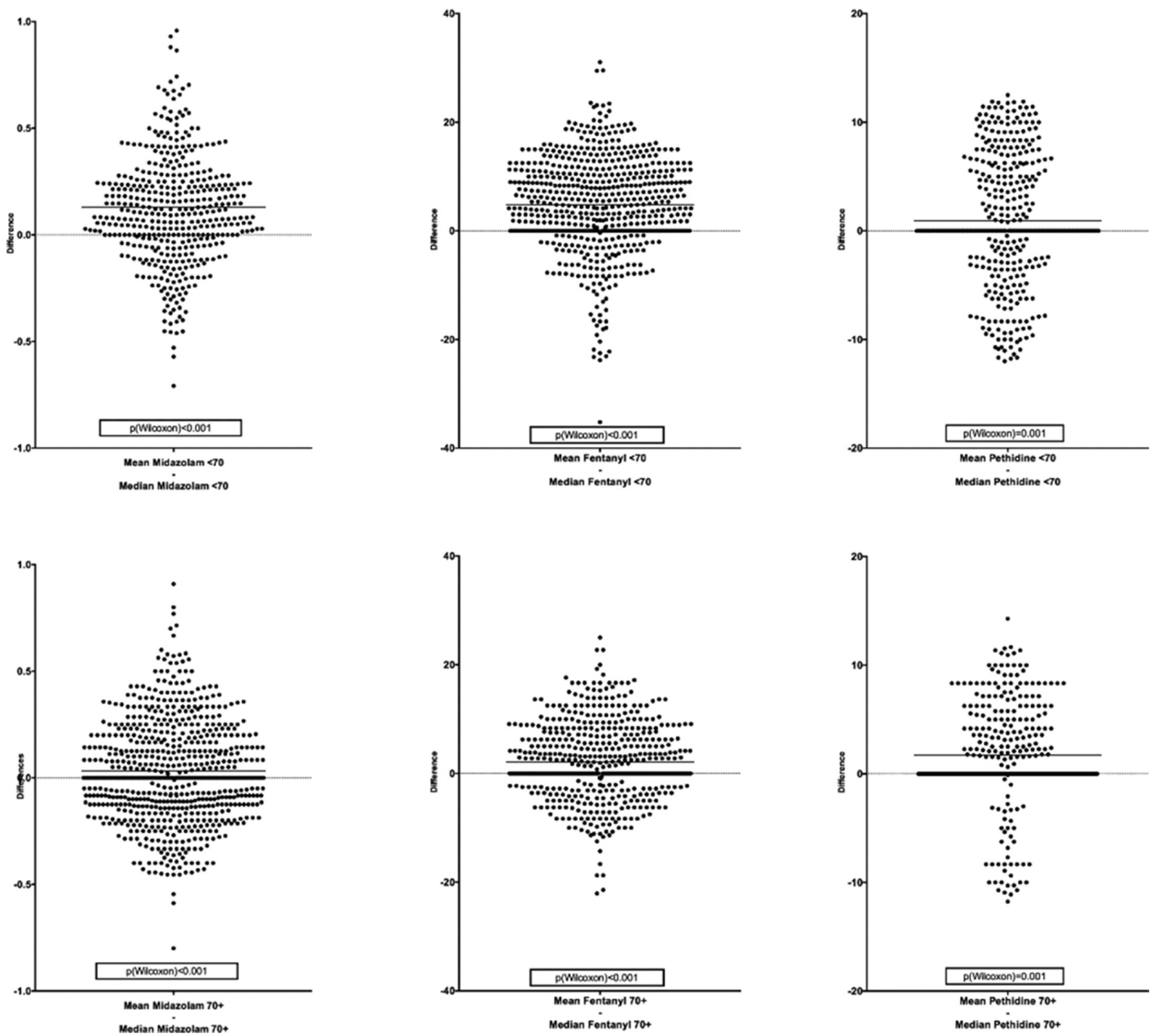

Abstract PTH-144 Figure 1 Scatterplot demonstrating differences between mean and median averages for each trainee's sedation KPIs. Thick line denotes median of differences and thin line denotes the mean of differences.

pairwise comparisons of KPI data made using Wilcoxon and McNemar's tests.

Results 733 trainees performed 36650 procedures with $\mathrm{M}$ (75.6\%), F (49.6\%) and P (25.3\%). Normality testing indicated the skewed distribution of sedation doses, which supported the use of medians. At trainee-level, changing mean to median resulted in smaller average doses of $\mathrm{M}, \mathrm{F}$ and $\mathrm{P}$ for patients aged $<70$ and $70+$ (figure 1 ), with lower estimates in 41.6\%. Fewer trainees exceeded the $2.5 \mathrm{mg}$ midazolam dose threshold in $70+$ (table 1) when averaged with median $(4.4 \%)$ vs. mean $(8.1 \%)$ [ $<<0.001]$. In this group, limiting the median $\mathrm{M}$ dose from $2.5 \mathrm{mg}$ to $2 \mathrm{mg}$ led to an increase in trainees failing to meet this standard (from $4.4 \%$ to $10.7 \%$, $\mathrm{p}<0.001)$. Overall, the change of KPI measurement increased the proportion of trainees exceeding the new sedation threshold at PCC from $8.1 \%$ to $10.7 \%(p=0.010)$.

Conclusions The JETS sedation KPIs have aligned with UK standards. As this may affect trainee outcome, all colonoscopy trainees and trainers should take note and exercise caution with sedation use, particularly in elderly patients.

\begin{tabular}{|c|c|c|c|c|c|c|}
\hline & M & & $\mathbf{F}$ & & $\mathbf{P}$ & \\
\hline Patient Age & $<70$ & $70+$ & $<70$ & $70+$ & $\begin{array}{l}< \\
70\end{array}$ & $70+$ \\
\hline Trainees & 732 & 729 & 607 & 579 & 392 & 346 \\
\hline Trainees>JETS* (mean) & $0.1 \%$ & $8.1 \%$ & $0.2 \%$ & $10.2 \%$ & 0 & $0.9 \%$ \\
\hline Trainees>JETS* (median) & 0 & $4.4 \%$ & 0 & 0 & 0 & $0.3 \%$ \\
\hline $\begin{array}{l}\text { Trainees }>\text { UK standards } \\
\text { (median) }\end{array}$ & 0 & $10.7 \%$ & 0 & 0 & 0 & $0.3 \%$ \\
\hline
\end{tabular}

